\title{
水溶液の $\mathrm{pH}$ に ほすす高壓の影響
}

岡山大学医学部生理等教室（士任林 香苗教授）

助手丹原英昌

[昭和 27 年 4 月 15 日受稿]

\section{I 緒 言}

大和 ${ }^{3)}$ は高圧の赤血球荷電に及ばす影響を 調へ，その祭緩衝液を用ひると変化が認めら れないのに他の酸性の液の場合には加厈に由 つて液がフルカリの方へ移動した様な成績を 得て, 高压飞由つて液の水素イオン指数 $(\mathrm{pH})$ が変化する事を推定した。著者2) る亦高圧の 下で Diastase 飞由る淑粉分解の作用が如何な る変化を受けるかを実験した際に，液の $\mathrm{pH}$ が王に由つて中性に傾く事を示す成績を得た。 反之 Ebbecke ${ }^{1)}$ は高匤に由つて溶液の解離度

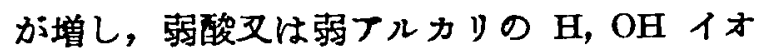
ンが强く解離する結果酸又はフルカリはその 度が增し，筋肉では此の変化が央要な役割を 演ずるものと考へた，本実験は種々の溶液の $\mathrm{pH}$ が加圷に由つて如何に変化するかを直接 知ら5と云ふ目的で行つたものである。

\section{I面羷方法}

、高压に対して緶密に出来て居るボンべ內に 被検半電池のみを入れて，標準半電池例へば 甘秉電極をボンべ外飞置いて高压化由る $\mathrm{pH}$ の変化を測定する事は，両半電他を連結する プリッチの設置が不可能な為出来ない，と云 つて，ボンベ內の容皘は直径 $2 \mathrm{~cm}$ 深さ $9 \mathrm{~cm}$ К足らず狭小な為，第 1 図の如き小型のキン ヒドロン電極を組立てボンべ內のモビル油中 そ涴して実験を行つた. 即ち 3 本の細い硝子 管（直径 $6 \mathrm{~mm}$ 長さ $7 \mathrm{~cm}$ )の下端を封したるの を杀でしぼつて 1 組とし，キンヒドロンで飽 和した被検液と摽潐縓衝液とを入れた 2 本の 管は飽和 $\mathrm{KCl}$ 寒天橋により飽和 $\mathrm{KCl}$ 溶液を 入れた管を中介として連絡せしめ，被検液及 び栖潐液には直径 $1 \mathrm{~mm}$ の白金線を入れ，銅
線に依つてボンベ の蓋を通して外部 に萁き出して两液 間の電位差を測定 した. 此の電極は 上部モビル油と接 触する部が油で污 れるので每回取換 へたが，白金線は 使用する度每㳊石 硢で洗ひクローム 硫酸飞浸し水洗乾 燥乙更洔时硝酸 を以て清淨にして 用ひた。

電位差の測定に は島津製の $\mathrm{K} 2$ 型 Potentiometer 及び 同社型の L型 Galvanometer (Sens.

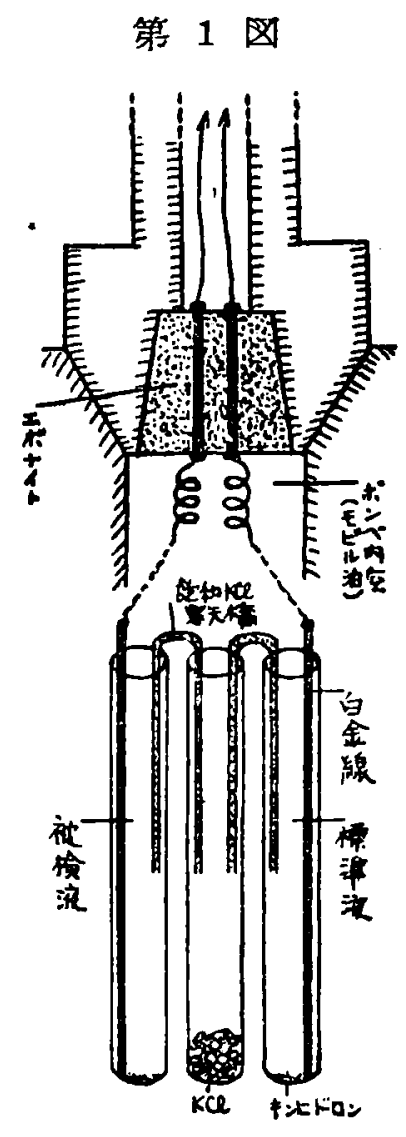
$69 \times 10^{-6} \mathrm{~V}$ ) を使用した.

本実験に於ては高压飞由る溶液の $\mathrm{pH}$ の变 化を調べるのがその目的であるから，使用し 一た溶液の $\mathrm{pH} の$ 絕文的な值は必ずしる正確に 知る事を必要としない，そこで棒準液として 用ひた液の $\mathrm{pH}$ は, 酸性酒石酸カリの能和溶 液の $\mathrm{pH}$ を 3.57 として次式を用ひて計算し て求め, 更に此の值から被検液の $\mathrm{pH}$ をる求 めた。

$$
\mathrm{pH}=\frac{\mathrm{E}}{0.0001983 \mathrm{~T}}+\text { St. } \mathrm{pH}
$$

Eは起電力； Tは絕対温度 ; St. $\mathrm{pH}$ は 標準液の $\mathrm{pH}$. 今温度を $\mathrm{t}^{\circ} \mathrm{C}$ とし $18^{\circ} \mathrm{C}$ を基隼として表は すと 


$$
T=(273+18)+(t-18)
$$

故泥 $\mathrm{pH}=\frac{ \pm \mathrm{mV}}{57.7+0.2(\mathrm{t}-18)}+$.St. $\mathrm{pH}$

䐼準本電池よりる被検電極の電位の方が高い 時は起電力 $(\mathrm{mV})$ は負数の方を取る.

溶液の調製に就ては以下の各項に述へる。 加圧実験は 100 気圧から 500 気压迄流就て行 つた，佾 1 回の実鍳を終了するにはキンヒド ロン能和後 30 分內外を要した関係から此の 電極の不安定な $\mathrm{pH} 7$ より高い溶液について の実験は行はなかつた。

\section{I 宽驗成綪}

此の方法に佉ると王に由る秈液間の起電力 の差の変化は求められるが溶液の $\mathrm{pH}$ の変化 を直接知る事は出来ない，とこで先づ標準と して用ひた綏㣫液の $\mathrm{pH}$ は王に由つては変ら ないるのとし，被検液とした液との電位差の 匠次変化は被検液の水素イォン活量 （ $a_{\mathrm{H}} ）$ の変化汇基くと考へる事にして測定観 察した。 その観察值をグラフにして示す.

グラフには上記電位差を從軸に取つた。 そ の際目盛は被検液が酸性の度を增すと小さく なる様にする，横軸にはキンヒドロン飽和後 電位差を湘定する時迄の時間を取り，第2区 以下K示した．図中のOは大気王即ち常压を， 1〜5は加へた压力（単位 100 気圧）を，Mは pH 測定用 3 硝子管がモビル油中に滠した事 を示す.ボンべ內の全空間はモビル油で充填

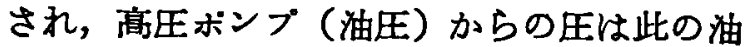
を通して 3 硝子管飞及心゙.

A. 强電解質溶液の $\mathrm{pH}$ が加圧に宙 つて如何に変るかに就ての実験

標準液としては Mislowitzer の標準醋酸塩 溶液 (Standard acetate) 即ち $0.1 \mathrm{~N}$ 醋酸液及 び $0.1 \mathrm{~N}$ 醋酸ソーダ液の等量を混じた縟得液 を用ひた. 此の液の $\mathrm{pH}$ は 4.62 となる筈で あるが既に迅べた様に，実験に先だつて時々 酸性酒石酸カリの飽和溶液を以て測定してお き，その值は各項に示した．强電解質液とし て塩酸を用ひて行つた実験成績を以下に述へ ๖.
1. 䄪0.1N 位となる様に蒸溜水で唏 积し た $\mathrm{HCl}$ 液を被検液とし，pH4.73 の醋酸熄 溶液を標準液として臣の上下による起宣力の 変化を調へた，その成緽は第 2 图に示した様 飞压を加へると電位差は減少し，その度は匡 の强さに大体比例して居る，今 500 気圧の場

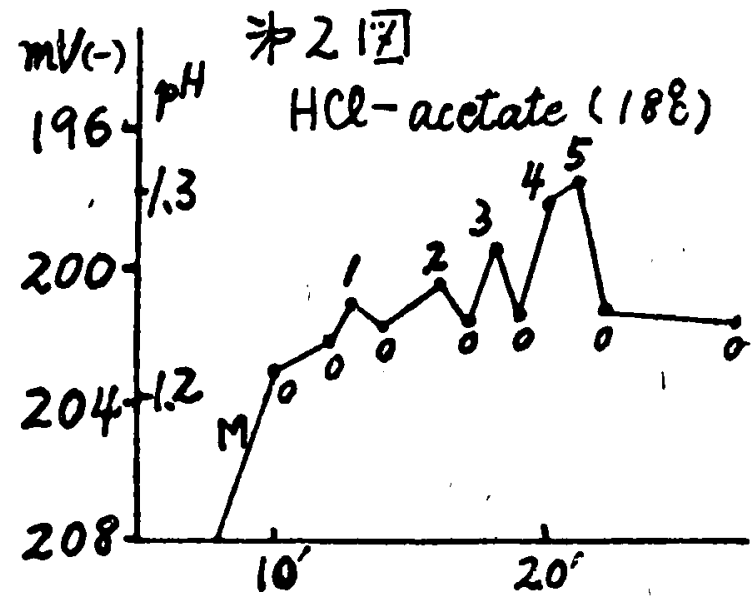

合の変化を見ると， $\mathrm{pH} 1.24$ のすのが $\mathrm{pH}$ 1.31 Кなって居り，pHで 0.07 の增加が見 られる．之を水素イオン活量（的）火して 計算すると，500 気庄で $17 \%$ の成少となる. 佁王を加へ叉は去つた際の電位差の変化は非 常に速かであり，此の事は以下総ての例で見 られた,

2. 次に此の $\mathrm{HCl}$ 液を 10 倍飞稀积した液 を被検液とし，同じく $\mathrm{pH} 4.73$ の醋酸塩溶液 を標準液として実験を行つた，その成紸も亦 第 3 因の如く圧の强さに比例して丽位差は減 少して居る。 $\mathrm{pH} 2.37$ の液は 500 気压の加压 飞由て $\mathrm{pH} 2.45$ となり 0.08 の增加即ち $a_{\mathrm{H}}$ は約 $19 \%$ 減少を来した事となる。

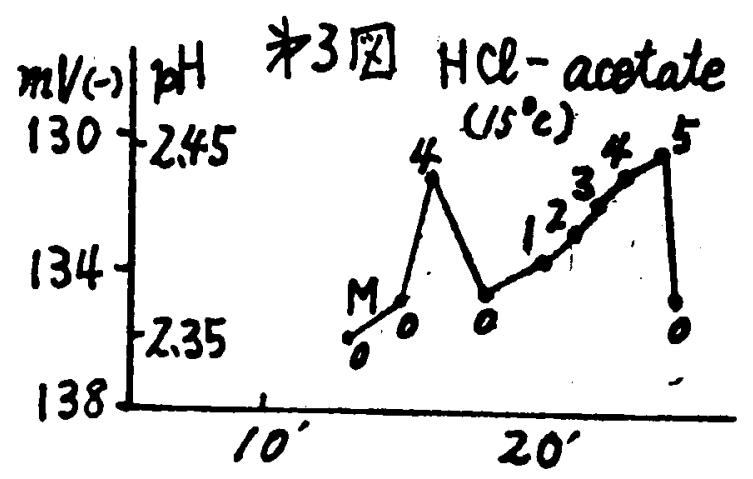

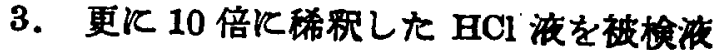
とし，pH 4.73 の醋酸塩溶液を标等液として 


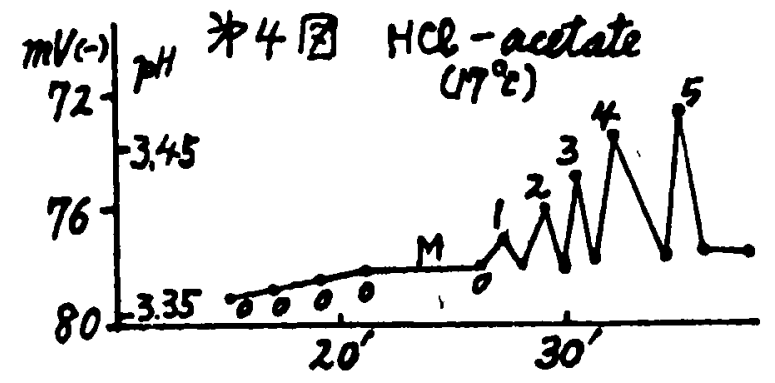

同様な実験を行つて第 4 困に示した．此の場 合飞る亦圷を加へる事に由つて電位差は減少 し，加入る压が高い程減少する電位差も大と なつた. 500 父压の場合を見ると， $\mathrm{pH} 3.39$ のものは加区飞由つて $\mathrm{pH} 3.48$ となつた事 となり 0.09 だけ $\mathrm{pH}$ の增加となる. える $a_{\mathrm{H}}$ として見ると約 $22 \%$ の減少を来した事とな る.

以上 $\mathrm{HCl}$ 液を段々稀釈して被検液とした 3 例に於て，標售とした pH 4.73 の縓街液であ

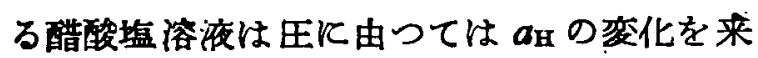
さないるのとすると， $\mathrm{HCl}$ 液の $a_{\mathrm{H}}$ は压を 加へると隇少する即ちよりフルカリ性の方に 移動すると云ふ成嘖を得た．而して $a_{\mathrm{H}}$ の減 少の度は加へた医が商けれぱ高い程大となつ ている，而して 500 気压飞於て減少する $a_{\mathrm{H}}$ の割合は $17 \%, 19 \%, 22 \%$ HCl 液が 10 倍, 100 倍と稀秎の度が强い程減少する割合 が大となつた。

\section{B. 抲電解質溶液の $\mathrm{pH}$ が加压火由} つて如何に変るかに就ての実験

蒻電解質溶液として醋酸の大体 $0.1 \mathrm{~N}$ の溶 液を被検液として用ひ， $\mathrm{pH} 4.73$ の標準醋酸 要溶湤を以て同梾な実験を行つたがその成綪 は第 5 因の如く HCI 液に於けると同粎に加 王の結果酸度が減少する傾向が認められ，成 埥が一定して居るので加へた臣の高さに比例 して居る事がよく分る，500気圧の加殴で

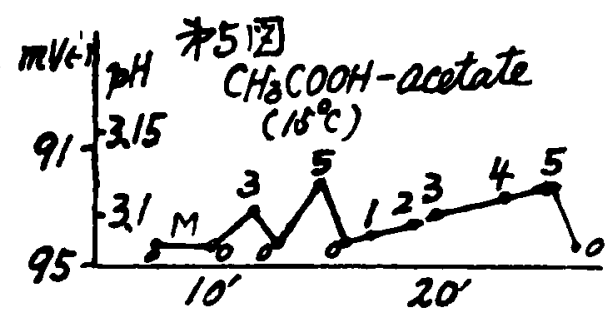

$\mathrm{pH} 3.08$ の醋酸溶液は $\mathrm{pH} 3.12$ 亿移動した事 となり $\mathrm{pH}$ として 0.04，a $a_{\mathrm{H}}$ で $9 \%$ 動いた事 そなる。をを $\mathrm{pH}$ の大体同じ $\mathrm{HCl}$ 液飞就て の前迅の成辕（第 4 叉）飞比較すると， $\mathrm{HCl}$ 液では 500 気压の加王で $a_{\mathrm{H}}$ が $22 \%$ 減少し て居るのに対し醋酸では $9 \%$ の咸少しか見ら れず，强電解質 HCl 飞比し灵電解質なる醋 酸の方が加圧に由る影響は遥かに少ない。

C. 緩街液を被検液として用ひた時 の加王に就ての実験”

今泛の被検液の $\mathrm{pH}$ は総て標準醋酸塩溶液 の $\mathrm{pH}$ はその液の楥㣫作用で王に由つては変 化を受けないるのとし，被検液の $\mathrm{pH}$ のみが 変るものとして計算したのであつたが，果し て緩徆液の $\mathrm{pH}$ は加王飞由つて影響されない るのであららか，若し影斟されないるのとす ると被検液他他の緩街液を用ひたならば加圧 飞由る電位差の変化は起らない事となる。そ こで 2 種の緩衝液の間では加圧に由つて如何 に電位差の変化が現はれるかに就て寨験を行 つた.

新たに用ひた䌊衝液は Mc. llvaine に徒つ て $0.1 \mathrm{M}$ 枸䋇酸及び $0.2 \mathrm{M}$ 第 2 燐酸ソーダ 液の種々の混合液である。

実験の結果敬いた事飞は緩衝液を被検液と した 2 種の䌊衝液相互の間の電位差す加圧に 由つて㚆化した. 此の加圧時観測した電位差 の移野を，仮に一方を標集とした液（甲）の $\mathrm{pH}$ は変らないるのとし，他方の液（乙）の pH のみが変化するとして測定した電位差の 変化をグラフに示し，且つ計算して見ると次 の通りとなつた.しかし計算の基準液を甲乙 交代して即ち乙液の $\mathrm{pH}$ が変らないるのと仮 定すると甲液の移動は前の乙液の $\mathrm{pH} の$ 移動 の計算の場合と逆方向になる事は言ら迄すな い: 下記実験 1 亿その例を示す.

1. 標準醋酸塩溶液と枸䋇酸燐酸ソーダ 溶液との組合せ

pH 4.31 の醋酸塩溶液と $\mathrm{pH} 2.47$ の枸橉 酸燐酸ソーダ溶液とを組合せたるのを加圧す ると電位差が減少する. 此の成綪を仮飞 $\mathrm{pH}$ 高き前者の $\mathrm{pH}$ は加压江由つては変らないる 

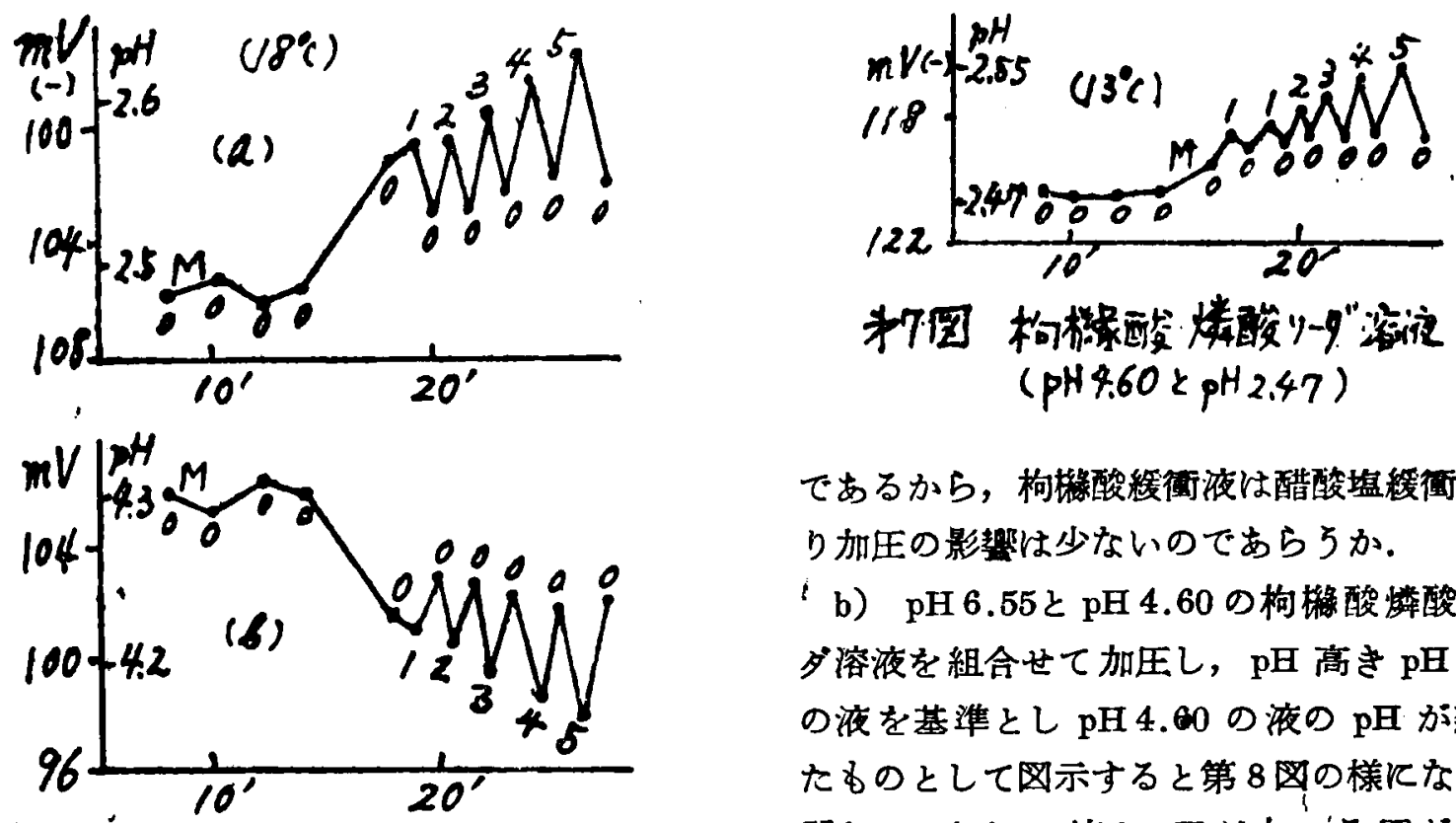

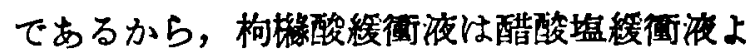
り加圧の影帮は少ないのであらうか。

'b) $\mathrm{pH} 6.55$ と $\mathrm{pH} 4.60$ の构䋇酸燐酸り一 ダ溶液を組合せて加圧し， $\mathrm{pH}$ 高き $\mathrm{pH} 6.55$ の液を基準とし $\mathrm{pH} 4.60$ の液の $\mathrm{pH}$ が变つ たものとして図示すると第 8 困の様になる， 即ち $\mathrm{pH} 4.60$ の液の $\mathrm{pH}$ は加へる王が高い 程激しくフルカリの方に移動する．500 気圧

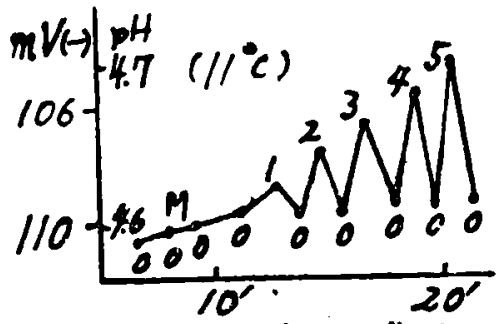

2.63 と 0.07 の増加即ち $a_{\mathrm{H}}$ では $19 \%$ の減 少を示した事となり，强電解質 $\mathrm{HCl} の \mathrm{pH}$ 移動と略同じ程度の $\mathrm{pH}$ 移動となる．此の成 精を $\mathrm{pH}$ の低き构䋇酸燐酸ソーダ溶源を基準 として醋酸塩溶液の $\mathrm{pH}$ が変つたるのとして 計算して図示すると第 10 因（b）の如くにな り，醋酸塩溶液の $\mathrm{pH}$ は酸の方に移動し，500 気压沈於ては $\mathrm{pH} 4.24$ が 4.17 となり $a_{\mathrm{H}}$ で $19 \%$ の増加を来した事になる。

2. $\mathrm{pH}$ の異る 2 つの枸格酸燐酸ソーダ溶 淮の組合せ

2) $\mathrm{pH} 4.60$ と $\mathrm{pH} 2.47$ の枸淥酸燐酸У 一ダ溶液を組合せて加压し，その成績を $\mathrm{pH}$ 高き pH 4.60 の液を基準とし，pH 2.47 の液 の $\mathrm{pH}$ が変つたものとして园示すると第 7 因 の様になり $\mathrm{pH} 2.47$ の液の $\mathrm{pH}$ は区飞応じ て大となる，500気圧の場合には $\mathrm{pH} 2.51$ の すのが 2.55 となり $\mathrm{pH}$ で 0.04 の増加， $a_{\mathrm{H}}$ で $9 \%$ の隇少となつた。然し醋酸塩䋧衙液 pH 4.73 と組合せた際より $a_{\mathrm{B}}$ の娍少が軙度

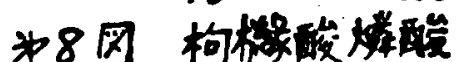

ソ-9"溶液

$(\mathrm{pH} 6.55<\mathrm{p}+4.60)$

に由つて $\mathrm{pH} 4.60$ の液が $\mathrm{pH} 4.69$ となり， $a_{\mathrm{H}}$ で $22 \%$ の減少を示した事となる. 即ち枸 格酸緩行夜水於ても加压の影響が此較的少な いといふわけではない。

D. 標準半電池をボンべ外飞置いて の実験

標準液が匠の影響を受けない椂にする為に ボンべ外飞置き，第 9 図の様な組合せを作り 牛電池 A B ボンべ內に入れて匠に電位 差の変化を測定した。此の場合 $\mathrm{A} ， \mathrm{~A}^{\prime}$ Kは キンヒドロンで飽和した同じ液を用ひた。

1. $\mathrm{pH} 4.60$ の醋酸塩溶液を用ひて加压実 験を行つた．標準斗電池はボンべ外にあるか ら変化しないが，ボンべ內の被検半電池は加・ 匠火由つて電位の低下が見られた，加へる圧 が高い程電位の低下す著しく，500 気圧飞由 


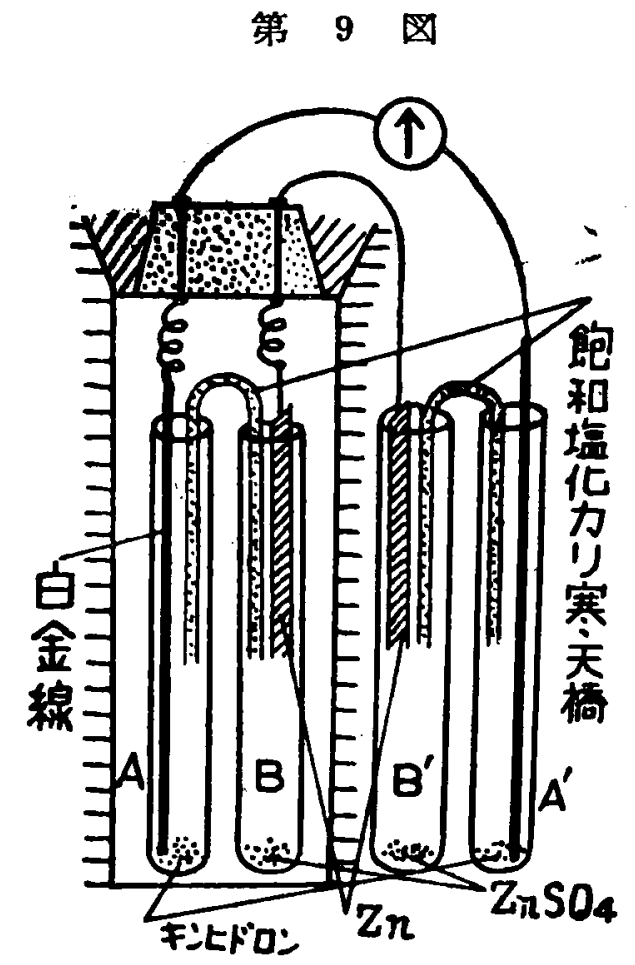

つて pHで0.15 ルカリ側に移動した事に なり、ので $42 \%$ 減少した事となる。

2. $\mathrm{pH} 2.37$ のCl 液を用ひた場合飞る やはり王に由つて被検半電池の電位は低下し た. その度は醋酸塩溶液に比べると非常に少 なく, 500 気圧では $\mathrm{pH} に し て 0.09$ フル り側に移動した事になり， $a_{\mathrm{II}}$ で $22 \%$ 減少 した事となる。

\section{IV 考察}

王に由つて電解質溶液の $\mathrm{pH}$ が変るか否か を理論的に検討すると次の様になる。

一般に或物質の活量を $a$ とし之が $\mathrm{v}$ 立の 液中的酉分子溶けて居るとすると，压 （P）と活量の変化 $(\mathrm{d} a)$ 結局は活量係数の変 化 (dr) との間には一定の関係が有る. 即ち

$$
\frac{\mathrm{d} a}{a}=\frac{\mathrm{d} \mathbf{r}}{\mathrm{r}}=\frac{\overline{\mathrm{V}}}{\mathrm{RT}} \mathrm{dP} \quad\left(\mathrm{V}=\frac{\partial \mathrm{V}}{\partial \mathrm{n}}\right)
$$

$\overline{\mathrm{v}}$ は楁㴶內の溶質 1 瓦分子の容槙であり， 匠の変化が少ない場台には活量の変化は目立 たないが，上記実験の如く非常に大きな区币 は其の変化す当然目立ち得るわけである.

、萑酸溶液の場台飞 $\mathrm{H}^{+}$の活量を $a_{\mathrm{B}}$, 活量 保数を的とするる

$$
\begin{aligned}
& \mathrm{pH}=\log \frac{1}{a_{\mathrm{H}}}=\log \frac{1}{\mathrm{r}_{\mathrm{H}}\left[\mathrm{H}^{+}\right]}=\log \frac{1}{\mathrm{r}_{\mathrm{H}}[\mathrm{HCl}]} \\
& =-\log \mathrm{r}_{\mathrm{H}}+\log \frac{1}{[\mathrm{HCl}]} \\
\therefore & \frac{\mathrm{dpH}}{\mathrm{dP}}=-0.4343 \frac{1}{\mathrm{r}_{\mathrm{H}}} \cdot \frac{\mathrm{dr} \mathrm{r}_{\mathrm{H}}}{\mathrm{dP}} \\
\therefore \mathrm{dpH} & =-0.4343 \frac{\overline{\mathrm{V}}}{\mathrm{RT}} \mathrm{dP}
\end{aligned}
$$

但し $a_{\mathrm{H}}=\mathrm{r}_{\mathrm{H}}\left[\mathrm{H}^{+}\right]$であり $\frac{\mathrm{d} a}{a}=\frac{\mathrm{dr}}{\mathbf{r}}$ である。

位つて医源り $a_{\mathrm{H}}$ が変化し, 従つて $\mathrm{pH}$ が変る事となる。

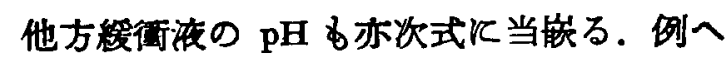
ば 且A なる弱酸の馛语液の $a_{\mathrm{H}}$ は

$$
\frac{a_{\mathrm{H}} \mathrm{r}_{\mathrm{A}}[\mathrm{A}-]}{\mathrm{r}_{\mathrm{HA}}[\mathrm{HA}]}=\mathrm{K} \quad \therefore a_{\mathrm{H}}=\mathrm{K} \frac{\mathrm{r}_{\mathrm{HA}}[\mathrm{HA}]}{\mathrm{r}_{\mathrm{A}}\left[\mathrm{A}^{-}\right]}
$$

故に此の $\mathbf{r}_{\mathbf{A}}, \mathbf{r}_{\mathrm{HA}}$ が塩酸の $\mathbf{r}_{\mathbf{H}}$ と同様に

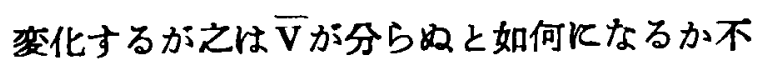
明である。

ヌキンヒドロンで電位差を測定する場合に はキンヒドロン自身の活量が電位差に関係し, 之が压の影響を受ける.

一吖に述へた様に匠に由つて綏衝液並にキ ンヒドロンす亦変化するが，その程度は不明 である．今若し强電解質浩液の活量の圧飞由 る変化が緩㣫液及びキンヒドロンのそれに此 して著しく大であるならば，正に由つて强電 解質溶液の $\mathrm{pH}$ が何れの方向飞傾くかを知る 事が出来るわけであり，此の考への下に実験 を行つたるのである。その結果强電解質溶液 では pHは中性任傾く事が同はれ，弱電解質 溶液である醋酸溶液でも同様で且つ之と $\mathrm{pH}$ の大体等しい塩酸の場合より電位差変動の度 が少なかつた.しかしながら次に行つた 2 種 の緩重液を組合せた場合に就て見ると，電位 差は区ほ由つて甚だしく㚆動するるのがあり， その程度は强電解質溶液と緩㣫液を組合せた 場合と大差がない，以上の理論並に実験事実 からして被梌液と緩行液とを組合せた電池る 全部ボンべ內に入れてその電压変化から被㭘

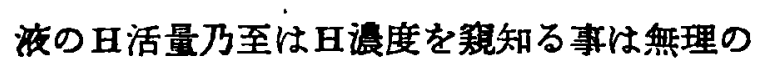
样に見えるので標蕉半電池をボンべ外飞置き 被検斗電池のみを加圧し電位差の発生を稓湘

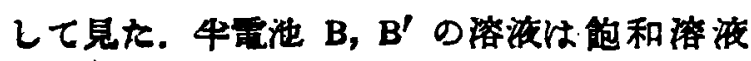




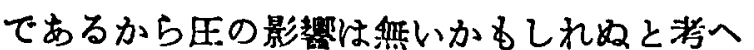
たのである．然し此の組会せでる上記実験が 示す様们期待した成縝は得られなかつた。徒 つて緩行液若しくはキンヒドロンの王に由る 活量の変化が，强電解算溶液の場合飞比して 甚だしく小さいるのであると考へる事は出来 ない，そこで最す条件の简単なものとして塩 化銀䉓極で硝酸銀溶液の活量が王力で如何に 变るかを検定して見度いと考へたのであるが， ボンベ中にある此の電極の電位差の変動を観 剆する牛電池の組合せ方の適切なるのが見当 らない。

\section{V 總 括}

小型のキンヒドロン電極を組立て〉全体を モビル油中に涴して，100 500 気圧の下で電 位美が如何に変動するかを測定した，その成 辚を総括すると，加へる匠に比例して電位差 は变化する．今次の两液の組合せで 500 気压 の下では

文

1) Ebbecke, U., Pflügers Arch., 157, 79, 1914.

2）丹原英昌：本呿。
1. 醋酸塩緩行流（pH 4.6 4.7） と次の 液との組合せ：一 $\mathrm{pH} 1.2 \sim 3.4$ の㙁酸では 4〜 $5 \mathrm{m \nabla}, \mathrm{pH} 3.1$ の醋酸では $2 \mathrm{m \nabla}, \mathrm{pH} 2.5$ の

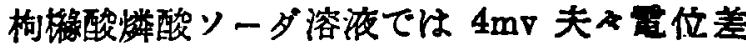
が減少した。

2. $\mathrm{p}$ 且 の異る构䋇酸燐酸ソーダ溶液の組 合せ：一 $\mathrm{pH} 4.6$ と $\mathrm{pH} 2.5$ とでは $2 \mathrm{m \nabla}$, $\mathrm{pH} 6.6$ と $\mathrm{pH} 4.6$ とでは $5 \mathrm{~m} \nabla$ 何れる電位差 が減少した。

3. 同じ牛電池の一方をボンべ外に異いて 他方を加压した場合：一pH 4.6 の醋酸塩楥 衝液では $19 \mathrm{mv}, \mathrm{pH} 2.4$ の塩酸では $5 \mathrm{m \nabla}$, 500 気圧を加へた牛電池の電位が低下した。

之等の実験成績から溶液の且活量が仕に由 つて如何に変るか一義的に說明する事は難し い. 牛電池の組合せ法に無理があるかと考へ るが適切な改良が見付からない。

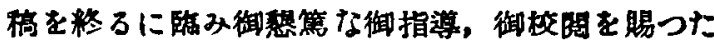
恩師林教挼並に御助言を戴いた吉村寿人教誩，西田 助教授に深即する。

献

3) 大和人士：本誌.

4) 吉村寿人： $\mathrm{pH}$ の理踚と其の店用.

\section{研究室で容易に作れる Variable Chronograph}

岡山大学医学部生理学教室 (主任 林 香苗教授)

助手 丹原英昌

[昭和 27 年 3 月 15 日受稿]

\section{I 緒 言}

我々の研究室に晋通常備している従来の描 時器飞は何分乃至何十分といふ長い時間々隔 のすのはなく，㭙間も 1 秒， 5 秒， 1 分とい ふ様に限られているので，長い時間に亘つて 䌊僈な変化を描写せしめて観察する際に，同 特に時をる併記せしめるには不便な場合があ
る。そこで任意の長い㭙間々隔を以つて時を 描かしむる装置で，しかす村料が容易に入手

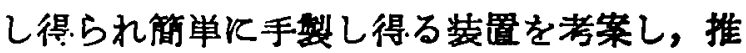
獎するに足ると考へるので報告する。

\section{II主旨と柿置}

装置の全貌は写真の如くでありその主要な 部分を第 1 図に示した。考案の主旨は一定の 